\title{
Smart Specialization of Innovative Development of Functional Territories: Strategic Experience and Potential of Ukraine
}

\author{
Hanna Kucherova ${ }^{1 *}$, Inessa Khvostina $^{2}$, Dmytro Ocheretin ${ }^{3}$, and Olha Bilska ${ }^{1}$ \\ ${ }^{1}$ Classic Private University, Chair of Economics, 69002 Zaporizhzhia, Ukraine \\ ${ }^{2}$ Ivano-Frankivsk National Technical University of Oil and Gas, Department of Applied Economics, 76019 Ivano-Frankivsk, \\ Ukraine \\ ${ }^{3}$ Zaporizhzhia National University, Faculty of Economics, 69600 Zaporizhzhia, Ukraine
}

\begin{abstract}
The article examines the strategic experience of introducing smart specialization in Ukraine using the methods of strategic analysis, financial analysis, generalization, statistics, critical thinking. It has been proved that the state priorities of Ukraine's strategic development have changed. The concept of providing state aid to industries that cannot withstand competition has been changed to the concept of identifying specialized functional areas based on the principles of reasonableness, sustainability and inclusiveness of development, the ability to integrate into value chains of world markets. The above more locally meets the requirements of the competitive environment, minimizes the risks of scattered financing, increases the level of effectiveness of strategic planning, innovative and technological development of the state as a whole. The inconsistency of the state and regional strategic support for the introduction of reasonable specialization was established against the background of determining the effectiveness of the use of such forms of cooperation as the cluster model and cross-functional interaction. The need for standardization and greater regulation of the smart specialization procedure at both the conceptual, methodological and practical levels is determined. Ukrainian smart specialization is constrained by the insufficient potential for the implementation of regional development strategies, the urgent need to adapt the method of assessing smart specialization in the format of entrepreneurial discovery to the Ukrainian realities of types of economic activity, insufficient funding of potential functional territories, low initiative, diversification and self-organization. The delay in the implementation of reasonable specialization of activities in Ukraine is explained by the need for additional time to reconfigure the socio-economic system at all levels and to understand the territorial needs, the prospects of choosing from existing opportunities and its consequences.
\end{abstract}

\section{Introduction}

In the context of active information technology development, European initiatives have identified a range of new prerogatives and challenges to modern regions and industries of developed and developing countries. The development concept was transformed from innovative to smart by declaring the concept of smart specialization for the functioning and development of regions, thereby maximizing the angle of view on modern socio-economic processes and the competitive potential for their improvement. In practice, this approach allows not to scatter funds, but to focus funding on truly unique objects or entities, whose potential is characterized not only by innovation, self-development, but also by the ability to self-integration into chains of added value formation on world markets.

Ukraine has received further European initiatives and is gradually introducing the concept of smart specialization. The European Union has not established clear rules and requirements for the introduction and irealizatation of smart specialization. The restriction concerned only the strategic vector, platform and general assessment methodology. And this is understandable, since smart specialization is a weakly structured category, and the specificity of its formalization and determination methodology depends on the characteristics of the subject or object of assessment, so the approach must be adaptive.

On the one hand, the permissive nature of the introduction of smart specialization does not limit, but on the other requires the immediate development of new skills, knowledge, and most importantly - the formation of a new vision of those very territories and industries, the principles of their development. The non-regulation of the procedure for introducing smart specialization will eventually reveal as a test separately those subjects that, in fact, are already functioning in a new, innovative, unique way, but are limited in development by certain parameters.

Smart specialization of economic activity introduces the identification and diversification of assets such as knowledge, experience, resources, business models, mechanisms of functioning, innovation, and form functional territories of interregional and transnational levels by means of cross-functional interaction. 
Thus, the scientific approach substantiates the principles of entrepreneurial discovery, the government forms a vision for assessing the opportunities, sentiments, trends, needs and prospects of smart specialization, business and society determine the entrepreneurial choice of market opportunities. The effect of qualitative and structural transformations as a result of smart specialization of activities is multidimensional, therefore, it is not only a quantitative assessment of trends and structural indicators.

Thus, the priority steps in the countries have been taken, the factors that inhibit and promote the implementation of smart specialization have already been identified, which requires careful study and research in each country separately.

\subsection{Ralated works}

The formation and development of an innovative economy is the only priority way of developing socioeconomic systems to ensure their life in the long term. The newest European direction is the introduction and development of smart specialization as a policy of unity of three basic principles: rationality, resilience and uniqueness of growth $[1,2]$. This concept is still only spreading, but it was first mentioned in the materials of the Knowledge for Growth - K4G concept, where its content was interpreted as a promising strategy for encouraging investment in areas that should complement the region's production assets to create its internal potential and interregional comparative competitive advantages in the future [1, 2]. Since the approach is based on the principle of searching for an entrepreneurial discovery, its implementation will ensure a qualitative change in the production function of the industry, will reveal the potential of the functional territory by means of using modern knowledge and technologies. The foundation of smart specialization lies in the concept of global growth and is presented in the European Union strategy document "Europe 2020. A European strategy for smart, sustainable and inclusive growth". The importance of the regional potential for the implementation of smart specialization is outlined in the provisions of the European Union document "Regional Policy for Smart Growth in Europe 2020". The main goal of smart specialization is the formation of a list of activities with high added value, which would strengthen the competitive position of the territory, pulling up related industries with less potential, and financing would be concentrated on the most promising activities.

Given the vagueness of the concept and the absence of a rigid and principled methodology, the EU's arsenal contains only a set of tools and a recommended methodological approach, the features of which are arbitrary choice and depend on the capabilities and goals of individual regions. There is also a lack of approved quality and efficiency criteria, statistical data in general. The effectiveness of the implementation of smart specialization today is assessed only by expert means.
Modern scientists study smart specialization in the context of the fourth innovation spiral, the interdependence of the knowledge economy, science and the competitiveness of industries, regions $[3,4,5,6]$. Separate studies are devoted to the advantages and disadvantages in the practical implementation of the smart specialization policy $[7,8,9]$, the factors influencing it $[10,11]$, in particular the actions of universities [12] and the institutional structure [13], study the experience of implementing relevant measures in different countries [14,15], the features of the strategic promotion of the concept $[16,17]$, the assessment of various implementation policies [18], the typology of regional diversification models [19], and so on.

The problems of the formation of competitive advantages of territories [20], the search for a synthesis of regional, cluster, structural and innovation policies of territories and the state as a whole [21], the implementation of innovative and structural diversification of socio-economic processes [22] and the importance of introducing individual strategies of smart specialization at the regional level [23]. The results of generalization by the European Union of monitoring, expert assessments, surveys of stakeholders of smart specialization are presented in [24], where a positive attitude is proved and the prospects of this direction of increasing the innovativeness of activities in Ukraine are assessed. Today, the experience of various countries is of scientific and practical value, in particular, the mechanism for introducing smart specialization launched in Ukraine. State priorities have already been identified and there is already a certain strategic experience in the implementation of certain measures, which requires a thorough study.

\subsection{Strategic experience of Ukraine}

During a long period of the country's development, the following is noted: the necessary macroeconomic strategic documents and measures are approved at all levels, but the expected result is not achieved. The reasons in each case are different, including insufficient funding, its fragmentation, lack of action plans or their partial or complete failure to implement. This is confirmed by the results of the analysis of individual programs for the creation of innovative instructions, reforming state policy in this area. Also, park structures have been created, a significant number of which, with some exceptions, have already existed for a long period only on paper or operate on a limited basis without a real return on investment and effort.

Repeated attempts were made to approve a single strategic document that would generalize the ways of solving issues regarding the innovative development of the country's economy; drafts of innovative development strategies were developed, which were never approved in the proposed version. In the future, some of their provisions were partially used as the basis for the development of the next project. For example, the draft Strategy of innovative development of Ukraine for 2010-2020 in the conditions of 
globalization challenges included certain provisions of previous documents. However, the document was never approved, although it was adopted by the Cabinet of Ministers of Ukraine and submitted for consideration by the Verkhovna Rada of Ukraine.

The foundations of reasonable specialization in all spheres of life are laid down in such a strategic document of Ukraine as the Concept of development of the digital economy and society of Ukraine for 2018 2020 and approval of the action plan for its implementation. In 2019, the Strategy of the development of the innovative activity sphere for the period up to 2030 [25] was approved, which ensures the organization of activities in building a modern innovation ecosystem for the long term and is the basis for transforming new fresh ideas into innovative products, increasing the level of innovativeness of the economy. In accordance with the provisions of Strategy 2030, it is proposed to apply new approaches in determining territorial priorities, including with respect to ensuring the quality of connections between participants in the innovation process by introducing digital technologies, applying the concept of smart specialization to implement the exclusive aspects of each territory.

Despite the recommendations of the European Union, Ukrainian specialists have artificially and expertly identified the following list of regional specializations: resource materials; bioeconomics and biotechnology; energy and power engineering; aerospace technology; information and communication technologies; healthy society. The Ukrainian understanding of smart specialization focuses on the search for a reasonable specialization of regions, competitive advantages, uniqueness and ways of decentralization within the boundaries of the industrial complex (the draft of the Strategy for the development of the industrial complex of Ukraine for the period until 2025), although the vision of the European Union is broader than one industry.

Overcoming sectoral limitations on the basis of Strategy 2030, it is planned to form strategies for regional innovative development, taking into account the needs and potential of the regions, and the Ministry of Education and Science of Ukraine, together with the central executive authorities, is determined to develop and submit a draft action plan for 2019 - 2021 to the Cabinet of Ministers of Ukraine within four months. years for the implementation of the Strategy [25], starting from 2022, to develop and submit for consideration by the Cabinet of Ministers of Ukraine draft three-year action plans for the implementation of the Strategy approved by this decree.

To assess the effectiveness of the implementation of the Strategy, it is envisaged to carry out both control over the implementation of action plans and monitoring their impact on various sectors of the economy. The monitoring procedure is developed by the Ministry of Education and Science of Ukraine together with the Ministry of Economic Development of Ukraine and other interested structures. The draft action plan for the implementation of the Strategy for the development of the sphere of innovation for 2019 -
2021 was approved by the order of the Cabinet of Ministers of Ukraine and published on the official website of the Ministry of Education and Science of Ukraine on November 29, 2019, but at the moment the monitoring procedure is not officially available.

Separate regional strategies for innovative development have not been approved today, and the provisions of the Strategy 2030 are included in regional strategies for the period 2021-2027, approved in accordance with the Draft State Strategy for Regional Development for 2021-2027 "Human-Centered Development and Unity", the need to prepare arose due to the expiration of the previous document [27] and the need to adjust regional policy in the face of new challenges.

The Ministry of Regional Development, Construction, Housing and Communal Services of Ukraine (from 29.08.2019 renamed to the Minister for Communities and Territories Development of Ukraine) on the official website on 13.03.2019 announced the start of work on the draft State Strategy for Regional Development of Ukraine until 2027.

At the moment, the regional development strategy is being developed in accordance with paragraph 1 of the fourth part of Article 8 of the Law of Ukraine "On the Foundations of State Regional Policy" and paragraph 5 of the Resolution of the Cabinet of Ministers of Ukraine dated 11.11.2015 No. 931 "On approval of the Procedure of development of the State strategy for regional development of Ukraine and the plan of measures for its implementation, as well as monitoring and evaluation of the effectiveness of the implementation of the said Strategy and plan of measures" [28] and taking into account the interests of the subjects of regional development in the State Strategy for Regional Development of Ukraine. It should be noted that the Draft of the 2021-2027 Regional Development State Strategy, formed in accordance with the requirements of the updated procedure for the development of regional strategies [28], included the need to use smart specialization in the implementation of the strategy, which is a new tool for realizing regional innovation potential based on the synthesis of the knowledge economy and local advantages, and makes it possible to determine the exclusivity of subjects, industries, regions. Technically, the approach provides for the definition of a set of competitive advantages, regional assets, scientific and innovative potentials, the use of which is effective only in the conditions of cross-functional and intersectoral interaction of all stakeholders (government, business, society, academic society). At the same time, clause 7 of Order 932 [29] determines that what is meant is that "regional strategies are developed for the duration of the State Strategy for Regional Development of Ukraine and must comply with its provisions" and in fact, regional strategies for the period 2021-2037 were developed mainly in accordance with the requirements provisions of the Draft of the 2021-2027 Regional Development State Strategy, taking into account the needs and potential of the regions and the Strategy 2030. So, basically, regional strategies for 2021-2027 were approved in the period from December 2019 to 
March 2020, that is, even before the approval of the 2021-2027 Regional Development State Strategy. It is worth noting the Strategy 2021-2027 for the Dnipropetrovsk region, the draft of which was approved on May 08, 2020 based on the provisions of the already approved State Strategy, and not its draft. Since the overwhelming majority of regional strategies were based only on the draft state strategy, then with the approval of its provisions, regional strategies should be completely revised in accordance with state strategic updates.

As a result of the analysis of the content of 27 existing regional strategies, it was found that the best probability of ensuring the achievement of strategic goals was determined based on the results of the SWOT analysis of regional development. In addition, they adhere to the legal requirements regarding the inclusion of at least one strategic goal of the regional strategy, which is determined on the basis of smart specialization and provides for the innovative development of priority types of economic activities in the region, the disclosure of the potential of functional territories, and an increase in the level of competitiveness of the regions.

However, although all regions approved plans for the implementation of the strategy, the implementation plan and the procedure for monitoring the state Strategy 2030 have not been approved. That plans requires approval, since, according to the requirements, regional strategies are based on certain state priorities for strategic development and without monitoring the effectiveness of the action plan, the provisions of state strategic documents will be declarative.

Also, the improvement of already approved regional strategies continues. For example, in August 2020, proposals were made to the Development Strategy of the Poltava Oblast till year 2027 to amend the socially oriented project - ensuring the availability of social services regardless of where you live. This confirms a flexible and adaptive approach to the strategic development of regions.

\subsection{Experience in the operation of functional territories}

Ukraine is introducing a smart implementation approach with the support of the European Commission's Joint Research Center directorate, which has developed analytical reports on the economic and innovation potential of three pilot regions: Kharkiv, Odesa and Zapirizhzhia oblasts, where, with the support of The Joint Research Center (JRC), an innovative approach is being introduced to implement a strategic planning - smart specialization (S3) and a comprehensive assessment and analysis of data is carried out according to the methodology of the European Union for the research of economic sectors, their priority is determined according to certain criteria, the best of which will be involved in the process of entrepreneurial discovery - the second stage of introducing smart specialization.

So, according to the Strategy of Regional Development of the Zaporizhzhia Region for the period up to 2027, Strategic Goal 2 is defined Competitive economy of the region (which develops on the basis of smart specialization) in the national and global space. It should be noted that the selection was made thoroughly and thoroughly, taking into account the available potential of types of economic activity and further opportunities for the development of related industries. and, if according to the results of a study by a group of experts from the Joint Research Center (JRC) of the European Commission, 19 types of economic activities were identified that can be recognized as having innovative potential in the Zaporizhzhia region, then according to the results of an in-depth study, only 8 types of activities were identified that can form the basis for the implementation of smart specialization in the Zaporizhzhia region. However, as a result, only 5 types of economic activities are included, namely: the production of endoprostheses, cables, equipment, motors, and so on.

In the Odesa oblast, also take palace the very carefully approached the choice of types of economic activity using smart specialization. While the initial selection included 198 industries, in total only 5 industries in the Odesa oblast showed both economic and innovation potential. The name of the strategic goals of the region was proposed: "Formation of an export-oriented food industry on the basis of innovations and the development of proposals for operational goals and objectives aimed at achieving a specific strategic goal." The priority direction of development was identified as "organic cultivation of vegetables, fruits and berries, production of processed products from organically grown products (canned vegetables, canned vegetables, pastes, sauces)". One of the effective forms of cooperation of all participants in the agrarian market, in order to minimize costs at all stages of production and marketing of agricultural products, a cluster model has been defined, which is budgetary in implementation and is based on the organizational mobility of the structure and coherence of interactions.

The Development Strategy of the Kharkiv Region for the period 2021-2027 and the Action Plan for 20212023 for its implementation define a separate goal: "to build a competitive and smart specialized spatial economy with high added value." Based on the assessment results, the following types of economic activities with high economic and innovative potential were identified: "production of basic pharmaceutical products and drugs, production of machinery and equipment, energy equipment, production of vehicles, trailers and semi-trailers and other vehicles".

The list of Regional Development Strategies until 2027 is given on the official website of The Ministry of Communities and Territories Development - 19 strategies, despite the fact that their overwhelming majority has been approved.

It should be noted that an updated approach to regional and sectoral development opens up new opportunities specifically for initiative regions, subjects of priority sectors of the economy, which positively affects the further formation and development of 
functional territories that create added value and continue the chain of its formation, even at the global level.

Thus, the state's attention is focused on the economic locomotives of the region, support for the development of which will stretch the associated related objects and sectors of the national economy, which will ensure the formation of a stable in time and specialized structure of the system of high-quality innovative economy of the state.

Thus, the approach of the Cherkasy region to achieve innovative changes in the economy of its region is interesting. Despite the fact that the region was not included in the three "pilot Ukrainian regions", on its own initiative, Cherkasy region registered on the smart specialization platform and established a connection with an interested party in the European Union in order to prove competitive advantages, hidden opportunities and prospects for unique development. This once again proves the promise of self-organization and initiative in matters of strategic innovative development of regions in the direction of smart specialization.

At the same time, the Strategy for Balanced Regional Development of Vinnytsia Oblast for the period up to 2027 defines the directions of smart specialization, namely: "the development of agricultural enterprises, the field of information and communication technologies and the development of health and medical tourism in the following areas: treatment heart diseases, musculoskeletal system and neuralgia, health rehabilitation of ATO / OSS participants ". And it is indicated that only after the adoption of the strategy implementation plan at the state level, the measures for the development of innovations in the region will be concretized. By this time, "dialogue platforms" will be formed for the implementation of intersectoral and intersubjective interaction of individual functional territories.

In 2019, within the framework of the project "Smart Specialization of Industry as a Trigger of Innovative Changes", the vision of 50 subjects of the industrial sector of Ukraine (sectors of the light, pharmaceutical, food industries) and government authorities was investigated by means of sociological research, namely, surveys [24]. The types of activities were selected according to the principle of determining growth prospects when applying the concept of smart specialization, the present high innovative development and a significant contribution to the formation of added value [24]. The study revealed a hierarchy of sensitivity to intellectual specialization from the R\&D stage, production and its greening, logistics, human resources, trade and so on [24]. Engineering, robotics, automation, data analysis, cloud technologies, artificial intelligence, blockchain [24], which are used in various activities to solve various, even opposite problems, are defined as the most promising technologies in terms of intelligence.

Thus, at the level of awareness in the Ukraine, smart specialization is rated at a high level and it is seen as a large-scale implementation process. The sequence of implementation of the concept of smart specialization by Ukrainian specialists and practitioners is seen in the first place at the level of functioning, and only then - at the level of development, which is logical for the promotion of the existing launch of new business processes.

However, the absence of an approved Action Plan for the implementation of the Strategy 2021-2027 disorients the development of industries and hinders the formation of functional territories. The lack of regulation of the smart specialization procedure, the limited range of certain criteria and monitoring, the lack of statistical reporting makes it impossible to substantiate reliable estimates of the implementation of smart specialization activities. In addition, the issues of financial support and self-financing remain very relevant for Ukraine.

\subsection{Financial and economic potential}

One of the main conditions for smart specialization is financial opportunity, since the realization of the potential is impossible without financial and economic support of the functional territory at the proper level. Consider the key financial indicators by type of economic activity in Ukraine.

The mining industry of Ukraine (Table 1) is not able to provide short-term liabilities (except 2018), since the Current Ratio $<100 \%$. Also, Cash Ratio $<20 \%$, therefore, cash and their equivalents are not enough to ensure the current obligations of the subjects of the complex. Value of index Equity-to-Assets $<50 \%$, therefore, the complex is characterized as insolvent. However, the net profit margin rises to $4.4 \%$ in 2019 .

Table 1. Mining and quarrying in Ukraine [30]

\begin{tabular}{|l|c|c|c|c|c|}
\hline Index & 2015 & 2016 & 2017 & 2018 & 2019 \\
\hline $\begin{array}{l}\text { Current } \\
\text { Ratio, \% }\end{array}$ & 89,6 & 93,3 & 98,7 & 103 & 84,7 \\
\hline $\begin{array}{l}\text { Cash } \\
\text { Ratio, \% }\end{array}$ & 1 & 1 & 1,9 & 1,3 & 1 \\
\hline $\begin{array}{l}\text { Equity-to- } \\
\text { Assets, \% }\end{array}$ & 18,1 & 16,9 & 18,4 & 33,8 & 30,3 \\
\hline $\begin{array}{l}\text { Return on } \\
\text { assets, } \\
\text { ROA \% }\end{array}$ & $-0,1$ & 0,1 & 0,8 & 3,4 & 1,6 \\
\hline $\begin{array}{l}\text { Net } \\
\text { margins, } \\
\text { NPM \% }\end{array}$ & 0 & 0,3 & 1,8 & 4,5 & 4,4 \\
\hline
\end{tabular}

The processing industry (Table 2 ) is able to provide short-term liabilities, Current Ratio $>100 \%$, but not with its own funds and their equivalents, Cash Ratio $<20 \%$. The industry's copywriting capacity increases sharply, but does not reach the standard value. Profit margin has almost halved.

The liquidity of agriculture, forestry and fisheries (Table 3) is decreasing, but as of 2019 it is more than twice the standard value. However, own funds are not enough to cover current liabilities. In general, the industry is solvent, the stability margin is strong. In the context of identifying unique subjects or technologies, it can become an object of smart specialization. 
Table 2. Processing industry in Ukraine [30]

\begin{tabular}{|l|c|c|c|c|c|}
\hline Index & 2015 & 2016 & 2017 & 2018 & 2019 \\
\hline $\begin{array}{l}\text { Current } \\
\text { Ratio, \% }\end{array}$ & 140,5 & 137,6 & 133,4 & 130,9 & 127 \\
\hline $\begin{array}{l}\text { Cash } \\
\text { Ratio, \% }\end{array}$ & 2,2 & 2,2 & 2,2 & 3 & 2,7 \\
\hline $\begin{array}{l}\text { Equity-to- } \\
\text { Assets, \% }\end{array}$ & 2,8 & 2,8 & 2,8 & 38,2 & 40,7 \\
\hline $\begin{array}{l}\text { Return on } \\
\text { assets, } \\
\text { ROA \% }\end{array}$ & 4,4 & 4,4 & 4,4 & 2 & 2,1 \\
\hline $\begin{array}{l}\text { Net } \\
\text { margins, } \\
\text { NPM \% }\end{array}$ & 3,9 & 3,9 & 3,9 & 1,5 & 1,7 \\
\hline
\end{tabular}

Table 3. Agriculture, forestry and fisheries in Ukraine [30]

\begin{tabular}{|l|c|c|c|c|c|}
\hline Index & 2015 & 2016 & 2017 & 2018 & 2019 \\
\hline $\begin{array}{l}\text { Current } \\
\text { Ratio, \% }\end{array}$ & 357,9 & 356,5 & 305,2 & 258,7 & 233 \\
\hline $\begin{array}{l}\text { Cash } \\
\text { Ratio,\% }\end{array}$ & 7,9 & 6,5 & 4,3 & 3,1 & 2,3 \\
\hline $\begin{array}{l}\text { Equity-to- } \\
\text { Assets, \% }\end{array}$ & 79 & 77,9 & 76,6 & 72 & 69,6 \\
\hline $\begin{array}{l}\text { Return on } \\
\text { assets, } \\
\text { ROA \% }\end{array}$ & 20,9 & 14 & 9,4 & 7,1 & 3,4 \\
\hline $\begin{array}{l}\text { Net } \\
\text { margins, } \\
\text { NPM \% }\end{array}$ & 25,5 & 19,4 & 12,2 & 8,9 & 3,9 \\
\hline
\end{tabular}

The trade and repair industry (Table 4) provides short-term liabilities, but cash and cash equivalents are not sufficient to meet current liabilities. The complex is characterized as insolvent, although the net margin is increasing.

Table 4. Wholesale and retail trade, repair of motor vehicles and motorcycles in Ukraine [30]

\begin{tabular}{|l|c|c|c|c|c|}
\hline \multicolumn{1}{|c|}{ Показник } & 2015 & 2016 & 2017 & 2018 & 2019 \\
\hline $\begin{array}{l}\text { Current } \\
\text { Ratio, \% }\end{array}$ & 116,6 & 117,6 & 116,5 & 114,8 & 115,5 \\
\hline $\begin{array}{l}\text { Cash } \\
\text { Ratio,\% }\end{array}$ & 4,5 & 4,6 & 4,3 & 3,6 & 3,8 \\
\hline $\begin{array}{l}\text { Equity-to- } \\
\text { Assets, \% }\end{array}$ & 16,3 & 17,6 & 18,1 & 17,4 & 19,8 \\
\hline $\begin{array}{l}\text { Рентабель } \\
\text { ність } \\
\text { активів, } \\
\text { RОА \% }\end{array}$ & 1,5 & 2,1 & 2 & 2,2 & 2,5 \\
\hline $\begin{array}{l}\text { Чиста } \\
\text { маржа, } \\
\text { NРМ \% }\end{array}$ & 0,7 & 0,8 & 0,9 & 0,9 & 1,1 \\
\hline
\end{tabular}

In the short term, the transport and storage sector (Table 5) is liquid only in 2017-2018. Current obligations are not secured. Solvency has not reached the standard value, and profitability has tripled.

The housing and catering industry (Table 6) shortterm liabilities cover almost a whole period. However, it does not cover current liabilities with its own funds. Insufficient level of solvency. The net profit margin has tripled.
Table 5. Transport, storage, postal and courier activities in Ukraine [30]

\begin{tabular}{|l|c|c|c|c|c|}
\hline Index & 2015 & 2016 & 2017 & 2018 & 2019 \\
\hline $\begin{array}{l}\text { Current } \\
\text { Ratio, \% }\end{array}$ & 96 & 99,4 & 100,7 & 100,8 & 93,6 \\
\hline $\begin{array}{l}\text { Cash } \\
\text { Ratio, \% }\end{array}$ & 4,3 & 3,5 & 4,4 & 4,1 & 3,9 \\
\hline $\begin{array}{l}\text { Equity-to- } \\
\text { Assets, \% }\end{array}$ & 36 & 37,6 & 36,6 & 39,1 & 38,4 \\
\hline $\begin{array}{l}\text { Return on } \\
\text { assets, } \\
\text { ROA \% }\end{array}$ & 0,3 & 0,8 & 0,6 & 0,9 & 1,3 \\
\hline $\begin{array}{l}\text { Net } \\
\text { margins, } \\
\text { NPM \% }\end{array}$ & 0,4 & 0,8 & 0,5 & 0,8 & 1,2 \\
\hline
\end{tabular}

Table 6. The housing and catering industry in Ukraine [30]

\begin{tabular}{|l|c|c|c|c|c|}
\hline \multicolumn{1}{|c|}{ Index } & 2015 & 2016 & 2017 & 2018 & 2019 \\
\hline $\begin{array}{l}\text { Current } \\
\text { Ratio, \% }\end{array}$ & 99 & 102,3 & 99 & 101,6 & 100,5 \\
\hline $\begin{array}{l}\text { Cash } \\
\text { Ratio, \% }\end{array}$ & 7,3 & 8,4 & 9,3 & 7,6 & 7,4 \\
\hline $\begin{array}{l}\text { Equity-to- } \\
\text { Assets, \% }\end{array}$ & 46,8 & 40,7 & 40 & 30,2 & 40,3 \\
\hline $\begin{array}{l}\text { Return on } \\
\text { assets, } \\
\text { ROA \% }\end{array}$ & 0,3 & 0,9 & 0,8 & 1,5 & 1,3 \\
\hline $\begin{array}{l}\text { Net } \\
\text { margins, } \\
\text { NPM \% }\end{array}$ & 0,2 & 0,5 & 0,4 & 0,6 & 0,6 \\
\hline
\end{tabular}

The sector for the supply of electricity, gas, steam and conditioned air (Table 7) in terms of liquidity and solvency did not reach the standard values. There is an unprofitable activity.

Table 7. Supply of electricity, gas, steam and conditioned air in Ukraine [30]

\begin{tabular}{|l|c|c|c|c|c|}
\hline Index & 2015 & 2016 & 2017 & 2018 & 2019 \\
\hline $\begin{array}{l}\text { Current } \\
\text { Ratio, \% }\end{array}$ & 88,5 & 88,5 & 84,2 & 85,4 & 75,5 \\
\hline $\begin{array}{l}\text { Cash } \\
\text { Ratio, \% }\end{array}$ & 4,1 & 3,5 & 3,2 & 3,1 & 2,8 \\
\hline $\begin{array}{l}\text { Equity-to- } \\
\text { Assets, \% }\end{array}$ & 21,3 & 13 & 9,6 & 4,9 & 5,3 \\
\hline $\begin{array}{l}\text { Return on } \\
\text { assets, } \\
\text { ROA \% }\end{array}$ & $-2,4$ & $-2,1$ & $-1,2$ & $-0,7$ & 0 \\
\hline $\begin{array}{l}\text { Net } \\
\text { margins, } \\
\text { NPM \% }\end{array}$ & $-2,6$ & $-1,5$ & $-1,2$ & $-0,8$ & 0,1 \\
\hline
\end{tabular}

Against the background of the failure to reach the standard liquidity values, the industry of water supply, sewerage, waste behavior (Table 8) is solvent. However, unprofitable activity is observed during the period under review.

The construction industry (Table 9) provides shortterm liabilities, but current liabilities are not covered by its own funds. Also, the industry is characterized by insolvency. Net margin is insignificant, increased by $50 \%$ over the period and is $1.2 \%$ in 2019 . 
Table 8. Water supply, sewerage, waste management in Ukraine [30]

\begin{tabular}{|l|c|c|c|c|c|}
\hline \multicolumn{1}{|c|}{ Index } & 2015 & 2016 & 2017 & 2018 & 2019 \\
\hline $\begin{array}{l}\text { Current } \\
\text { Ratio, \% }\end{array}$ & 95,2 & 85,9 & 94,6 & 88,9 & 93,6 \\
\hline $\begin{array}{l}\text { Cash } \\
\text { Ratio,\% }\end{array}$ & 2,8 & 3,8 & 4,9 & 3,3 & 4 \\
\hline $\begin{array}{l}\text { Equity-to- } \\
\text { Assets, \% }\end{array}$ & 71,3 & 65,8 & 66,1 & 64,8 & 67,1 \\
\hline $\begin{array}{l}\text { Return on } \\
\text { assets, } \\
\text { ROA \% }\end{array}$ & $-0,9$ & -1 & $-0,2$ & $-0,5$ & 0 \\
\hline $\begin{array}{l}\text { Net } \\
\text { margins, } \\
\text { NPM \% }\end{array}$ & $-1,9$ & $-2,5$ & $-0,4$ & $-0,9$ & 0 \\
\hline
\end{tabular}

Table 9. The construction industry in Ukraine [30]

\begin{tabular}{|l|c|c|c|c|c|}
\hline \multicolumn{1}{|c|}{ Index } & 2015 & 2016 & 2017 & 2018 & 2019 \\
\hline $\begin{array}{l}\text { Current } \\
\text { Ratio, \% }\end{array}$ & 108,6 & 112,3 & 107,8 & 107,5 & 108,4 \\
\hline $\begin{array}{l}\text { Cash } \\
\text { Ratio,\% }\end{array}$ & 2,9 & 4,6 & 3 & 2,3 & 2,3 \\
\hline $\begin{array}{l}\text { Equity-to- } \\
\text { Assets, \% }\end{array}$ & 19,6 & 21,4 & 20,5 & 19 & 18,2 \\
\hline $\begin{array}{l}\text { Return on } \\
\text { assets, } \\
\text { ROA \% }\end{array}$ & 0,5 & 1,1 & 0,9 & 0,9 & 1 \\
\hline $\begin{array}{l}\text { Net } \\
\text { margins, } \\
\text { NPM \% }\end{array}$ & 0,8 & 1,1 & 1 & 1,1 & 1,2 \\
\hline
\end{tabular}

The field of information and telecommunications (Table 10) provides short-term liabilities, but covered current liabilities with its own money only in 2019. Solvency decreased and in 2019 did not reach the standard value. The industry's profitability rose to $3.3 \%$ in 2019.

Table 10. The field of information and telecommunications in Ukraine [30]

\begin{tabular}{|l|c|c|c|c|c|}
\hline Index & 2015 & 2016 & 2017 & 2018 & 2019 \\
\hline $\begin{array}{l}\text { Current } \\
\text { Ratio, \% }\end{array}$ & 152,8 & 156,2 & 139,2 & 133 & 116,3 \\
\hline $\begin{array}{l}\text { Cash } \\
\text { Ratio,\% }\end{array}$ & 12,2 & 11,4 & 16,9 & 17,6 & 20,2 \\
\hline $\begin{array}{l}\text { Equity-to- } \\
\text { Assets, \% }\end{array}$ & 60,6 & 56,5 & 56,3 & 53,4 & 48,6 \\
\hline $\begin{array}{l}\text { Return on } \\
\text { assets, } \\
\text { ROA \% }\end{array}$ & 0,7 & 1,4 & 3,9 & 3,6 & 6,9 \\
\hline $\begin{array}{l}\text { Net } \\
\text { margins, } \\
\text { NPM \% }\end{array}$ & 1,1 & 2,1 & 2,6 & 2,9 & 3,3 \\
\hline
\end{tabular}

For the sphere of financial and insurance activities (Table 11), the data exceed the standard indicator of the Current Ratio by several times, but the current liabilities are not secured with own funds in 2019. On the whole, the industry is fairly solvent. The profit margin fluctuates at $1.9 \%$ in 2019 .

The real estate sector (Table 12) is liquid and solvent, but it does not cover current liabilities with its own funds. The share of net profit in sales increased to $3.3 \%$ in 2019 .
Table 11. Financial and insurance activities in Ukraine [30]

\begin{tabular}{|l|c|c|c|c|c|}
\hline Index & 2015 & 2016 & 2017 & 2018 & 2019 \\
\hline $\begin{array}{l}\text { Current } \\
\text { Ratio, \% }\end{array}$ & 634,5 & 702,2 & 593,9 & 556,5 & 508,3 \\
\hline $\begin{array}{l}\text { Cash } \\
\text { Ratio,\% }\end{array}$ & 26,3 & 30,3 & 32,3 & 23,9 & 19,2 \\
\hline $\begin{array}{l}\text { Equity-to- } \\
\text { Assets, \% }\end{array}$ & 86,2 & 87,3 & 84,7 & 83,8 & 82,6 \\
\hline $\begin{array}{l}\text { Return on } \\
\text { assets, } \\
\text { ROA \% }\end{array}$ & 0 & 0,1 & 0,1 & 0,1 & 0,1 \\
\hline $\begin{array}{l}\text { Net } \\
\text { margins, } \\
\text { NPM \% }\end{array}$ & 1,9 & 2,3 & 1,6 & 1,6 & 1,9 \\
\hline
\end{tabular}

Table 12. Real estate operations in Ukraine [30]

\begin{tabular}{|l|c|c|c|c|c|}
\hline Index & 2015 & 2016 & 2017 & 2018 & 2019 \\
\hline $\begin{array}{l}\text { Current } \\
\text { Ratio, \% }\end{array}$ & 105 & 103,1 & 101,7 & 101,7 & 103,6 \\
\hline $\begin{array}{l}\text { Cash } \\
\text { Ratio,\% }\end{array}$ & 1,4 & 1,5 & 3,4 & 3,4 & 2,9 \\
\hline $\begin{array}{l}\text { Equity-to- } \\
\text { Assets, \% }\end{array}$ & 68 & 65,6 & 64,8 & 62,2 & 64,5 \\
\hline $\begin{array}{l}\text { Return on } \\
\text { assets, } \\
\text { ROA \% }\end{array}$ & 0 & 0,1 & 0,2 & 0,5 & 1,2 \\
\hline $\begin{array}{l}\text { Net } \\
\text { margins, } \\
\text { NPM \% }\end{array}$ & 0 & 0,5 & 0,8 & 1,9 & 3,3 \\
\hline
\end{tabular}

During the period under review, the sphere of professional, scientific and technical activities (Table 13) is liquid. However, it covered current liabilities with its own funds only in 2016, and reached solvency in 2018. Profitability increased to $1.4 \%$ in 2019.

Table 13. Professional, scientific and technical activities in Ukraine [30]

\begin{tabular}{|l|c|c|c|c|c|}
\hline Index & 2015 & 2016 & 2017 & 2018 & 2019 \\
\hline $\begin{array}{l}\text { Current } \\
\text { Ratio, \% }\end{array}$ & 137,5 & 135,8 & 136 & 135,6 & 125,2 \\
\hline $\begin{array}{l}\text { Cash \% } \\
\text { Ratio,\% }\end{array}$ & 17,3 & 22,4 & 19 & 18,8 & 12,5 \\
\hline $\begin{array}{l}\text { Equity-to- } \\
\text { Assets, \% }\end{array}$ & 48,7 & 47,3 & 48,6 & 50,8 & 46,4 \\
\hline $\begin{array}{l}\text { Return on } \\
\text { assets, } \\
\text { ROA \% }\end{array}$ & 0,3 & 0,8 & 0,9 & 0,9 & 0,8 \\
\hline $\begin{array}{l}\text { Net } \\
\text { margins, } \\
\text { NPM \% }\end{array}$ & 0,9 & 1,5 & 1,6 & 1,7 & 1,4 \\
\hline
\end{tabular}

Despite the liquidity and ability to pay in the education sector (Table 14), the net profit margin decreased from $1.9 \%$ to $0.3 \%$ over the period.

In general, one can argue about the liquidity of the prevailing majority of Ukrainian industries, but there is a problem with covering current liabilities with own money and their equivalents. Solvent are agriculture, forestry, fisheries, water supply, sewerage, waste management, information and telecommunications, financial and insurance activities, real estate transactions, education. 
Table 14. Education in Ukraine [30]

\begin{tabular}{|l|c|c|c|c|c|}
\hline Index & 2015 & 2016 & 2017 & 2018 & 2019 \\
\hline $\begin{array}{l}\text { Current } \\
\text { Ratio, \% }\end{array}$ & 162,1 & 123,3 & 131,6 & 119,2 & 115,1 \\
\hline $\begin{array}{l}\text { Cash } \\
\text { Ratio, \% }\end{array}$ & 30 & 47,7 & 44,7 & 24,9 & 34,9 \\
\hline $\begin{array}{l}\text { Equity-to- } \\
\text { Assets, \% }\end{array}$ & 59,9 & 62,3 & 63,1 & 69,7 & 63,6 \\
\hline $\begin{array}{l}\text { Return on } \\
\text { assets, } \\
\text { ROA \% }\end{array}$ & 2,6 & 4,4 & 4 & 1,4 & 0,7 \\
\hline $\begin{array}{l}\text { Net } \\
\text { margins, } \\
\text { NPM \% }\end{array}$ & 1,9 & 4,1 & 2,4 & 0,9 & 0,3 \\
\hline
\end{tabular}

The share of net profit in sales is insignificant, but it is increasing; it is decreasing only in education, agriculture, forestry, fisheries, and the processing industry. The unprofitable sectors are the supply of electricity, gas, steam and conditioned air, the supply of water, sewerage, and waste management. Thus, in order to implement the concept of smart specialization of functional territories of Ukraine, it is imperative to ensure positive trends in the values of key financial and economic indicators by means of synthesis of selforganization of business entities and state support. This will have a positive effect on improving the business climate in the country [31-32].

\section{Conclutions}

In the context of European initiatives in building an innovative economy, the main role is played by the formation of smart specialization of cross-functional economic activity of the territory. In Ukraine, in this context, a new Strategic long-term document of innovative development has been developed, new requirements and priorities for innovative development of Ukraine have been developed. The advantages of the new state strategy include a departure from the territorial structure and the formation of ten functional territories of different types, the development of which is focused on the renewed goals and the existing potential, the disclosure of which is provided for by appropriate measures. In the future, it is proposed to overcome the ineffectiveness of the previous strategic documents by linking the implementation of state strategic standards, requirements, plans with the volume of state funding. Therefore, in the future, only actual smart entities and their cluster-functional associations will be provided with funding. The delay in the adoption of the State Strategy disorientated regional strategic development, as a result of which regional strategies were formed only on the basis of the provisions of the draft state strategy. However, regional documents are currently being revised taking into account the new challenges of our time, new European foundations in terms of introducing smart specialization of the activities of the regions based on the use of the proposed methodology of the European Union, which is based on the principles of SWOT analysis and building a flexible structure of intersectoral interactions. One of the effective forms of cooperation is the cluster model, which is budgetary when implemented and is based on the organizational mobility of the structure and sustainable interaction. Thus, smart specialization boils down to identifying those functional territories with different types of economic activity, which are as close as possible to European standards in terms of technological, socioecological and economic development, are unique, can function synchronously, compete with dignity and integrate themselves into the global value chain, shape the city's budget and labor market, thereby implementing a smart new strategic development policy. Such entities do not require significant funding to bring them to the European market, which is relevant given the budget deficit in Ukraine. For the maximum possible disclosure of their potential, only a well-organized organizational and informational model of identification and presentation in the world market, initiative and interaction with European stakeholders are lacking, which can be overcome at the state level with minimal costs. Problematic issues remain the quality of the formation and implementation of the regional development strategy, the adaptation of the method for assessing smart specialization to the Ukrainian realities, the level of funding only for those functional territories whose activities are practically implemented, comply with the standards and really have innovative and unique significance.

\section{References}

1. P. McCann, R. Ortega-Argilés, Reg Stud, 49(8), 1291-1302 (2015).

2. P. Balland, R. Boschma, J. Crespo, D. Rigby, Reg Stud, 53(9), 1252-1268 (2019).

3. E. Carayannis, E. Grigoroudis, Foresight, 10(1 (eng)) (2016).

4. A. Varga, T. Sebestyén, N. Szabó, L. Szerb, Reg Stud, 54(1), 1-12 (2018).

5. L. Höglund, G. Linton, R\&D Management, 48(1), 60-72 (2018).

6. S. Krammer, Technol. Forecast. Soc. Change, 123, 95-107 (2017).

7. R. Capello, H. Kroll, Eur Plan Stud, 24(8), 13931406 (2016).

8. H. Kroll, Eur Plan Stud, 23(10), 2079-2098 (2015).

9. P. McCann, R. Ortega-Argilés, Eur Plan Stud, 24(8), 1407-1427 (2016).

10. R. Hassink, H. Gong, Eur Plan Stud, 27(10), 20492065 (2019).

11. M. Trippl, E. Zukauskaite, A. Healy, Reg Stud (2019). DOI: 10.1080/00343404.2019.1582763.

12. M. Markkula, H. Kune, Technology Innovation Management Review, 5(10), 7-15 (2015).

13. M. Benner, Eur Plan Stud, 27(9), 1791-1810 (2019).

14. B. Asheim, M. Grillitsch, M. Trippl, Smart specialization as an innovation-driven strategy for 
economic diversification: Examples from Scandinavian regions. In Advances in the theory and practice of smart specialization, pp. 73-97, Academic Press (2017).

15. Y. Petrenko, E. Vechkinzova, V. Antonov, Insights into Regional Development, 1(2), 118-128 (2019).

16. D. Foray, The economic fundamentals of smart specialization strategies. In Advances in the theory and practice of smart specialization, pp. 3750, Academic Press, 2017.

17. E. O. Olaniyi, M. Reidolf, Journal of Security \& Sustainability Issues, 5(2), 213-227 (2015).

18. S. Radosevic, Assessing EU smart specialization policy in a comparative perspective. In Advances in the theory and practice of smart specialization, pp. 1-36, Academic Press, (2017).

19. K. A. Piirainen, A. N. Tanner, L. Alkærsig, Regional foresight and dynamics of smart specialization: A typology of regional diversification patterns. TECHNOL FORECAST SOC, 115, 289300, (2017).

20. D. Foray Structuring a policy response to a "Grand Challenge", URL:

http://ec.europa.eu/invest_in_research/pdf/downlo ad_en/selected_papers_en.pdf.

21. D. Foray, P. David, B. Hall, Smart specialization. From academic idea to political instrument, the surprising career of a concept and the difficulties involved in its implementation. MTEI Working Paper No. 2011.001. Lausanne, Ecole Polytechnique Federale de Lausanne (2011).

22. D. Foray, X. Goenaga, The Goals of Smart Specialisation. Luxembourg, Publications Office of the European Union (2013).

23. D. Foray, European Journal of Innovation Management, 17(4), 492-507, (2014).

24. M. Sychevskiy, L. Deineko, O. Kushnirenko, O. Tsyplitska, O. Deineko, Implementation of Smart Specialisation for Regional Industrial Development. In III International Scientific Congress Society of Ambient Intelligence 2020 (ISC-SAI 2020), pp. 323-331, Atlantis Press, (2020).

25. Stratehiia rozvytku sfery innovatsiinoi diialnosti na period do 2030 roku. Rozporiadzhenniam Kabinetu Ministriv Ukrainy vid 10.07.2019 № 526-r [Development strategy of the sphere of innovation activity for the period up to 2030. By the order of the Cabinet of Ministers of Ukraine dated July 10, 2019 No. 526-r], URL: https://zakon.rada.gov.ua/laws/show/526-2019$\% \mathrm{D} 1 \% 80 \#$ Text [in Ukrainian].

26. Derzhavna stratehiia rehionalnoho rozvytku na period do 2020 roku. Postanovoiu KMU vid 06.08.2014 № 385 [State strategy of regional development for the period up to 2020. Resolution of the Cabinet of Ministers of Ukraine dated 06.08.2014 No. 385], URL: https://zakon.rada.gov.ua/laws/show/385-2014$\% \mathrm{D} 0 \% \mathrm{BF} \#$ Text [in Ukrainian].

27. Ministry of Development of Communities and Territories of Ukraine (2019). State Strategy for Regional Development for 2021 - 2027 "Humancentered Development and Unity". Ministry of Development of Communities and Territories of Ukraine website, URL:

http://www.strategy.kharkiv.ua/docs/SSRD.pdf. [in Ukrainian].

28. Pro zatverdzhennia Poriadku rozroblennia Derzhavnoi stratehii rehionalnoho rozvytku Ukrainy i planu zakhodiv z yii realizatsii, a takozh provedennia monitorynhu ta otsinky rezultatyvnosti realizatsii zaznachenykh Stratehii i planu zakhodiv: Postanova Kabinetu Ministriv Ukrainy vid 11 lystop. 2015 r. № 931 [On approval of the Procedure of development of the State strategy for regional development of Ukraine and the plan of measures for its implementation, as well as monitoring and evaluation of the effectiveness of the implementation of the said Strategy and plan of measures: Resolution of the Cabinet of Ministers of November 11, 2015 No. 931]. URL:

https://zakon.rada.gov.ua/laws/show/931-2015p/ed20181117\#n76 [in Ukrainian].

29. Poriadok rozroblennia rehionalnykh stratehii rozvytku i planiv zakhodiv z yikh realizatsii, a takozh provedennia monitorynhu ta otsinky rezultatyvnosti realizatsii zaznachenykh rehionalnykh stratehii i planiv zakhodiv: Postanova Kabinetu Ministriv Ukrainy vid 11 lystopada 2015 r. № 932. Ofitsiinyi visnyk Ukrainy, 2015 r., № 92, st. 3131 [The procedure for developing regional development strategies and action plans for their implementation, as well as monitoring and evaluating the effectiveness of the implementation of these regional strategies and action plans: Resolution of the Cabinet of Ministers of Ukraine dated November 11, 2015 No. 932. Official Gazette of Ukraine, 2015, No. 92 Art. 3131] [in Ukrainian].

30. Ofitsiinyi sait analitychnoi systemy dlia komplaensa, analizu rynkiv, dilovoi rozvidky i rozsliduvan Youcontrol [Official site of the analytical system for compliance, market analysis, business intelligence and investigations Youcontrol]. URL: https://youcontrol. com.ua/(accessed: 05.11.2020). (in Ukrainian)

31. Ocheretin D., Los V., Kucherova H., Bilska O. An alternative approach to modeling the country's business climate in conditions of limited information, in E3S Web of Conferences, 166, 13024, (2020).

32. A. Uchitel, H. Kucherova, A. Didenko, O. Kravets, Y. Honcharenko, Scenario forecasting information transparency of subjects' under uncertainty and development of the knowledge economy, M3E2-MLPEED 2020, Odessa, Ukraine, July 13-18, 2713, CEUR-WS.org, online (2020), 
URL: http://ceur-ws.org/Vol-2713/paper05.pdf 